\title{
若い世代の取り組み
}

\section{グローバルヤングアカデミー におけるSDGsへの取り組み}

駒井章治

グローバルヤングアカデミー（GYA）と聞い てもピンとこない方がほとんどであろう。まず はGYAについて少しご紹介したい1。

GYA は世界の若手科学者の声」となること を目的とし、数年の世界経済フォーラムにおけ る準備期間を経て、2010年に正式に設立された 比較的新しい組織である。そのビジョンの実現 のために世界中で新しい才能ある人材を育成し、 つなげ、活性化を行ってきており、これらの活 動を通して若手科学者のエンパワーメントを進 めている。GYAは国や専門、世代を超えた対 話によるエビデンスに基づいた包括的な世界的 意思決定を行うことを目指している。会員は学 術的卓越性と活動への関与により選考され、そ の任期は 5 年である。30-40歳（博士取得後およ そ3-10年）の先進的若手研究者が 200 名所属し ており、その卒業生は2017年には134名に達し、

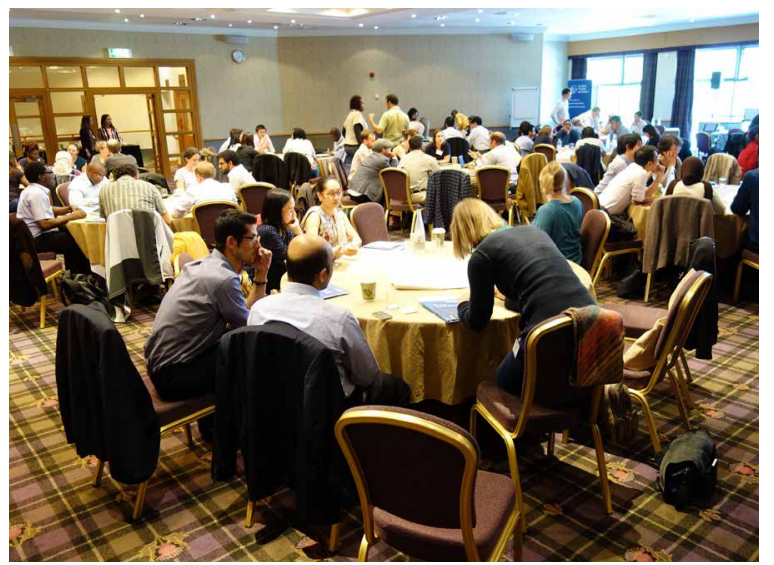

併せて 70 の国と地域のメンバーが一堂に会する 規模となった。我が国からも現役のメンバー 3 名を含む計 9 名がこれまでメンバーとしてその 役割を担ってきた²。

\section{GYAの取り組み}

ワーキンググループ (WG)

GYAの活動は科学、政策、研究環境や科学教 育とアウトリーチに焦点が当てられている。主 なプロジェクトとして若手研究者の状況把握 (Global State of Young Scientists: GloSYS) 研究 プロジェクトがあり、現在はAfricaやASEAN を中心に進められているほか、「難民奨学生イニ シアチブ」といった緊急プロジェクトにも取り 組んでいる。

更にその他のWGがSDGsとどのように関 連しているかについて幾つかの具体的な例を 挙げる。“Invisible Worlds” WGは、人類の意 図しない一連の活動に関して検討するもので、 3、5、6、7、8、9、10、11、12、13、14、15 や16といった多くのSDGSについても関わり 得るものである。“The Global State of Young Scientists”、 "Open Science”、“African Science Leadership Program"、 "Global Access to Research Software”さらに“Women in Science” 
などはSDGs 4、5、10および 17 との関連が想 定され。新しく形成された“Biodiversity and Biomedicine” WGで はSDGs 3、4、11、14、15 および 17 に関連するであろう。

更にGYAはその活動として各国の若手アカ デミー設立及び調整も支援しており、これまで 我が国をはじめ、エジプト、フィリピン、ジン バブエ、南アフリカ、ナイジェリア、イスラエル、 ケニア等の若手アカデミー設立に寄与し、共催 で地域会議や世界会議を開催してきた。このよ うな活動が後に述べる「声明」の発出につながっ たものと考えられる。

\section{対外活動}

GYA は国際科学政策や初期、中期キャリアの 若手科学者のおかれた研究環境に関して「世界 の若手科学者の声」を発出してきた。国連事務 総長サイエンス・アドバイザリー・ボード（2016 年末迄) やInterAcademy Partnership (IAP)、 欧州委員会共同研究センター $(J R C)$ 、国際科学 会議（ICSU）やGlobal Research Council（GRC） 等の国際科学組織との積極的な関わりも持ち、 世界的活動の一部に寄与してきた。GYAは先進 国と発展途上国との科学におけるギャップを、 異なる国からの若手科学者をつなげることによ り埋める努力を行っており、これらの活動を通 してGYAメンバーは科学者や研究者の自身の研 究がより社会に貢献する必要性を感じている。

現在までのところ、GYAの活動がSDGsに合 わせる形で整頓されているわけではないが、既 に進められているプロジェクトの多くがSDGs

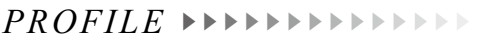

駒井章治（こまい しょうじ）

- 奈良先端科学技術大学院大学准教授

日日本学術会議若手アカデミー委員会前

委員長、グローバルヤングアカテミミー前

メンバー

專門 脳科学、行動科学

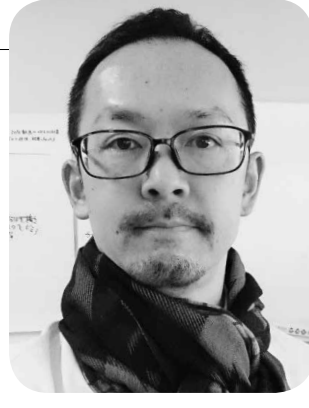

の促進に寄与できるものといえる。2015年に GYAが進めた世界若手アカデミー会議におい て「持続可能な開発」を中心的テーマに据えた ことからも明らかである。GYAはSDGs策定 の段階においても国連事務総長に書簡を提出 し、それぞれのゴールの重要な要素としての 科学や根拠の統合について意見を述べてきた。 2015 年 6 月のハイレベル政治フォーラムの第三 セッションに対してGYAは繰返し起こる感染 症への対策と持続的な天然産物薬の開発などを $\lceil$ Fablab」などを例に持続可能な方略について政 策概要を示した。2015年の世界科学会議ではサ イド・イベントとしてIAPやWorld Association of Young Scientists (WAYS)、 the International Consortium of Research Staff Associations （ICoRSA）と共にSDGsを議論する場をオーガ ナイズした。またGYAのメンバーや出身者が IAPにおけるSDGsに関連した二つのプロジェ クトにも参画している。多くのGYAにおけるプ ロジェクトやWGがSDGsに関連しており、固 形廃棄物やスマート・ビレッジ、難民問題など についても議論を深めている。

2016年6月の初のSDGsに関する国連STI フォーラム (Multi-stakeholder forum on STI) にもGYAからの多くの代表が参加した。同 年9月にブリュッセルで行われたGYA-JRCInternational Network for Government Science Advice (INGSA) ワークショップにおいても 
SDGsについて取り上げた。“Science, Education and Youth”WGでは終始そのテーマとして持 続可能な開発を取り上げており、幾つかの学校 でのプロジェクトにおいてSDGsを取り上げて きた。例えばカナダのNova Scotiaにおけるプ ロジェクトではSDG\#14を用い、何世紀にもお よぶ漁業とのつながりを理由に進められてき たローカルな歴史と持続可能性の関係について 探った。

GYAでは、彼らの活動とSDGsとの関連を今 後更に明示的に示すことも検討しつつあるよう である。

\section{SDGsに関する}

\section{各国若手アカデミーからの声明}

2017年10月26日にGYAから「国連SDGsの 達成に向けた各国若手アカデミーの役割」に関 する声明が発出された。これは同年7月に南ア フリカの若手アカデミーとGYAの共催により開 催された第三回世界若手アカデミー会合（南ア フリカ、ヨハネスブルクにて開催：下写真）に

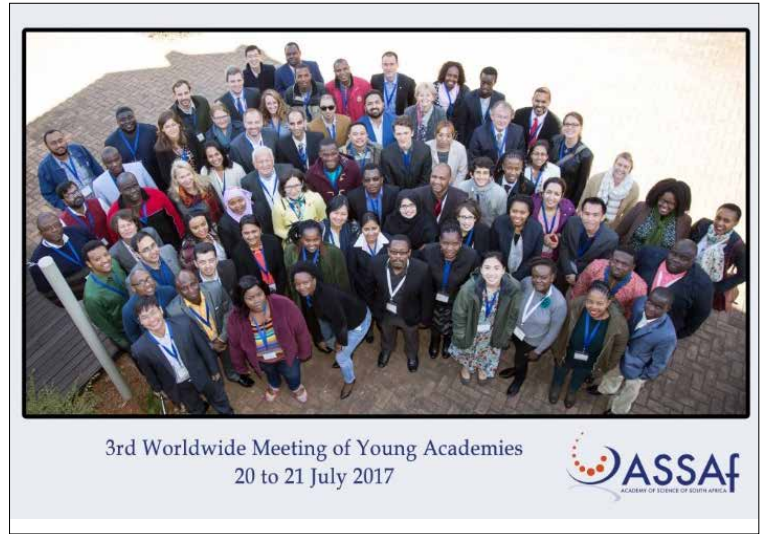

おける議論を受けたものであり、GYAと 36 の 各国若手アカデミー及び若手アカデミー・イニ シアティブによって取りまとめられたものであ る。これによると、若手科学者のSDGsに対す る取り組みとして主に以下三つの項目が挙げら れている。

・SDGsの達成のために専門を超えた形での 科学的助言と健全な政策提言を行うことに より、それぞれの国や地域、国際政策助言 システムから独立したものとして認識され ることを目指す。

・科学とパブリックの間をつなぐ優れた役割 としての若手アカデミーとの科学コミュニ ケーションを通して、児童や生徒、市民社 会やメディアにおけるSDGsの理解の向上 を行う。

・SDGsの実行やモニタリングにおいて若手 科学者をトレーニングすることで能力開発 を行う。

この声明を通してGYAは若手アカデミーが SDGs達成に向けた概念化、発展、実行戦略に 対して中心的役割を果たす意識を明確に示した。 更にはこの声明を通して各国ポリシー・メーカー やシニア・アカデミーに対して若手アカデミー や若手科学者との協働を促し、持続可能性を牽 引する「グローバル・サイエンス」に向かって 共に立ち向かうことを呼びかけた。 


\section{まとめ}

GYAでは、SDGsに関してはそれぞれを系統 立てた形での議論が始まったばかりで、アカデ ミーとして注力すべきゴールの選定についても 未だ定まっていない。しかしこれまで既に幅広 い領域において取り組んできており、その多く はSDGsとも強く関連している。メンバー自身 が取り上げた重要な課題に取り組むWGが活発 に活動しており、これらもSDGs と密に関係し ている。

対外的にも各方面のステークホルダーに対し て協働、共創を訴え、SDGs実現に向け理解の向 上と能力開発を通して寄与することを宣言した ところである。彼らは、与えられるのではなく、 未来を担う当事者として自ら考え、行動し始め た。今後GYAをはじめ各国若手アカデミーに よるSDGs達成に向けた取り組みが活発になり、 “No one left behind”の実現に向けた動きが推進 されることが期待される。今後の彼らの活動を サポートし、その上で世代の別をはじめあらゆ る垣根を取り除き、各人が「自分ごと」として 取り組む態度を示すきっかけとなることを切に 願っている。

注

1 Global Young Academy のホームページにはGYAに関する情 報が多数掲載されており、本レポートはこれを参考に執筆 したものである。声明や年次報告についても同ホームペー ジ（以下URL）に掲載されている。 https://globalyoungacademy.net/

2 うち2名が実行委員 (Executive Committee) として選出され、 その職務を果たした。筆者もそのうちの一人である。 